\title{
Effect of Job Demand and Support on Work-Family Conflict in Selected Banking Institutions in Ghana
}

\author{
Augustine Osei Boakye ${ }^{1}\left(\mathbb{D} \bowtie\right.$, Joseph Fiakpornu $^{2}$ (D), Samuel Yeboah ${ }^{3}$ (D) Prince Addai $^{4}$ \\ Ghana Communication Technology University ${ }^{1,2,3,4}$
}

\begin{abstract}
Purpose: This study investigated the effect of job demand and job support on employees' work-family conflict. Of paramount interest was to verify whether work-family conflict differed among male and female employees in the banking sector of Ghana.

Design/Methodology: This study used a descriptive survey design and a quantitative approach to collect data from banking institutions with the help of a standardized questionnaire. The independent sample t-test and multiple regression were used to analyze the data.

Findings: The study results showed that job demand had a positive effect on work-family conflict while job support also had a negative effect on work-family conflict. The study also revealed no significant difference in the experience of work-family conflict among males and females in the banking sector of Ghana.

Practical Implications: The study's findings indicate that for employees in the banking sector of Ghana to contribute their quota towards the competitiveness of their banks, there is the need for their work-family interface to be aligned appropriately through family-friendly policies, realistic job targets, and substantial work-resources.
\end{abstract}

\section{ARTICLE INFO}

Received: December 18, 2021

Accepted: January 13, 2022

Published: January 17, 2022

Keywords:

Job Demand

Job Support

Work-family conflict

Gender

(cc) BY (C) 2022 The Author(s)

\section{Introduction}

Work-family conflict (WFC) is a global concern that many organizations and employees face in this $21^{\text {st }}$ century (Mansour \& Tremblay, 2018). Accordingly, scholars and professionals from different backgrounds are all showing great interest in the issue of WFC since its disregard can have negative repercussions on employees and their organizations (Adisa, Osabutey, \& Gbadamosi, 2016). The two domains that play a paramount role in the life of every employee are the work and family domains. These domains involve various responsibilities that demand a high level of time and energy (Martínez-León, Olmedo-Cifuentes, \& Sanchez-Vidal, 2019). WFC happens when pressures and contradictory roles exist from both the work and family domains, which result in the incompatibility of the two domains (Sok, Blomme, \& Tromp, 2014). Available research indicates that poor 
organizational and family commitment, poor mental well-being, and poor job performance are some of the negative repercussions of WFC, thus making the quest for its control ever-pressing (Annor, 2016b; Mansour \& Tremblay, 2018; Morrison, Mensah, Kpakpo, \& Asante, 2020).

The Ghanaian culture of the extended family system, which provides sources of support to many employees in difficult times, has experienced substantial threat, as the relationship between family members is deteriorating due to rapid relocation and urbanization (Abotchie, 2008; Nukunya, 2003). This has led to the proliferation of the nuclear family system, which weakens the ties and support derived from the extended family in times of need (Annor, 2016a). Similarly, in the Ghanaian context, women play instrumental roles in the family in childcare, elderly care, and performing household chores (Osei Boakye, Dei Mensah, Bartrop-Sackey, \& Muah, 2021). However, the changes in the family system coupled with increased women's participation in paid work have rendered the performance of these roles difficult (Kundu, Phogat, Datta, \& Gahlawat, 2016), making work-family conflict much pronounced. Consequently, this has increased the number of persons who perform multiple roles across the work-life interface, such as dual-career couples, single parents, employed females, and fathers profoundly engaged in childrearing (Kundu et al., 2016; Osei Boakye et al., 2021).

Previous studies conducted by most researchers have depended on unbiased measures, namely, the ages and number of children in evaluating household demands on the work-family interface (Annor, 2016a; Eunice, Asiedu, Annor, \& Baah, 2018; Oren \& Levin, 2017) These studies contend that less energy is dedicated to professional work when having more children to take care of, as much energy is required. Given this, most researchers consider WFC as a women's issue. However, recent evidence indicates that WFC is a gendered issue experienced by both women and men (Adisa et al., 2016). Thus, it is generally difficult for many workers with parental roles to combine their family responsibilities with paid work. Hence, understanding job demand and job support and its effect on the work-family interface are of real prominence for both workers and employers. This will benefit employers and the labor force to resolve the challenges associated with job demand and its effect on work-family conflict in balancing the demands of work and household errands. Employers can also offer the necessary assistance to employees by improving any work-family conflict, which will intend to have vigorous, quality, and diligent human resources, thus nurturing communal agreement.

\section{Research Objective.}

The main objectives of the study are as follows:

1. To examine whether work-family conflict differs with respect to gender.

2. To investigate the effect of job demand and job support on work-family conflict.

\section{Significance of the study}

The study provided essential data for establishing alternative methods to manage job demand and job support and its effect on employees' work-family conflict. To be specific, the study was to benefit in the following ways.

1. Provide findings that the banking sector will use to aid its workers in embracing all-inclusive approaches that can benefit personnel to reduce work-family conflict.

2. The information generated and the findings would support sustaining the knowledge gap about concerns in the Ghanaian context, which are job demand, job support, and work-family conflict.

3. Provide findings that will be used by managers on addressing job demand, job support and work-family conflicting issues, and human resource managers in addressing employee's needs about the organizational goal. 


\section{Literature Review}

\section{Theoretical Review}

The complex forces at work related to the work-family domains have a necessary consequence regarding theory and research. Several theories have been propounded to explain why work and family responsibilities collide. The spillover theory will be revisited for this study to elucidate why individuals experience work-family conflict. The spillover theory was propounded by Staines (1980) to explain the consequences of juggling multiple roles. According to the spillover theory (Staines, 1980), emotions, conduct, attitudes, and feelings in both work and family domains frequently exceed the borders of those areas (Sok et al., 2014). The theory continues that these domains affect one another through previous frontiers, either negatively or positively (Sok et al., 2014). This denotes that spillover tends to affect both work and family. This usually emerges when a domain's emotions, attitudes, and conduct are affected by manipulating the other. For instance, satisfaction and achievement from work can result in satisfaction and happiness at home. Positive spillover results when skills and role performances in a given domain result in improved conduct, attitude, emotion which results in greater satisfaction, performance, or involvement in the other domain (Adisa et al., 2016).

The main emphasis of spillover theory is that attitude, emotion, conduct, and feelings experienced or learned in one domain tend to affect the other. On the other hand, negative spillover is experienced when forces from family and work domains are unsuited. For instance, when a worker has a dissatisfactory moment at work, there is the propensity to transfer such a distractive state to the house, which shall perpetually affect the household domain. Adisa et al. (2016) contended that negative spillover is associated with hours of work. This is because, hours of work are mostly comprised of massive job demand, and normally, less flexible. Consequently, this affords the workers fewer periods to cope with their household obligations (Adisa et al., 2016).

\section{Conceptual Review}

\section{Job Demand}

The concept of job demand constitutes any psychological and physical aspect of work that draws on one's physical or intellectual resources. This can take the form of work pressures and challenging task requirements (Fila, 2016). It can be deduced that "all other things being equal" if the job is too demanding or less can adversely affect employees' psychological well-being, performance, motivation, and work-family balance (Michel, Kotrba, Mitchelson, Clark, \& Baltes, 2011). Because of that, demands from one's work constitute an antecedent of work-family conflict.

\section{Job Support}

This implies the supportive interactions that employees receive concerning issues surrounding their work, usually with overseers and co-workers (Fila, 2016). It can be said that with healthy work support from the organization, peers, social support, and management, there is a propensity that employees can achieve a greater satisfactory result leading to the organization realizing its long-term objectives. Thus, improved associate assistance enhances the curtailment of work-family conflict. Kundu et al. (2016) suggested that supervisory support decreases job issues surrounding the work environs amongst workforces as it permits employees to partake in household responsibilities resourcefully. The provision of superior assistance to employees enables the implementation of a strategy that emphasizes the importance of balancing both domains and considers probabilities for employees to take advantage of such opportunities in decreasing conflict in both domains (Kundu et al., 2016). However, without adequate support, there is a tendency for employees to feel less motivated, which can affect their performance negatively. 


\section{Supervisor Support}

Kundu et al. (2016) assumed that supervisory support assists in decreasing issues surrounding the job and its environs between workforces, as it inspires employees in performing household duties proficiently. Consequently, providing superior assistance to employees enables the implementation of a strategy that emphasizes the importance of balancing both domains and considers probabilities for employees to take advantage of such opportunities in decreasing conflict in both domains.

\section{Co-worker Support}

This refers to essential support received from associates to complete errands by exchanging ideas and offering inspiration once required (Kundu et al., 2016). therefore, enhanced associate assistance in organizations tends to curtail conflict in both domains between workforces.

\section{Organizational Support}

The well-being of employees is paramount to every organization since they contribute significantly to the success and continuality of the organization. Previous studies found that when organizations provide support to their employees, it goes a long way to increase job satisfaction and balance their work-life. This support enhances employees to execute their tasks very well. An organization's ability to retain its employees depends on how well employees are treated and supported. Kundu et al. (2016) suggested that organizational support represent resources allied to fairness (discrimination), organizational rewards (intrinsic and extrinsic), and job condition (time, flexibility, information), which provide the needed support for an employee to balance their work and family role. It is argued that whenever employees identify they are receiving fair treatment from their co-workers, they notice more support.

\section{Work-Family Conflict}

It refers to instances where one's job responsibilities hinder household responsibilities or interfere with the work domain duties. This means that it becomes impossible to manage both job and household roles by workforces. Furthermore, it is whereby responsibility burdens regarding job domain and household domain remain equally dissenting with making an employee involved in one role (work) and another role (home) at the same time becomes difficult (Regeria \& Nairobi, 2017). In other words, such job and household interference exist when the anticipations set for one responsibility (work) provide no space for meeting the anticipations for other roles (home). This indicates that the work-family role is in two directions, meaning both roles have a diverse effect on the other. A study conducted by (Regeria \& Nairobi, 2017) mentioned resource-based, psychological-based, and behavior-based as the types of work-family conflict.

\section{Hypothesis Development}

\section{Gender and Work-Family Conflict}

Existing treatise on the association between gender and work-family conflict continues to be inconclusive (Starmer et al., 2019). For instance, in a comparative study of work-life balance from western and eastern perspectives, Chandra (2012) observed that people's responses regarding the job and household demands contrast transversely among nations considering the state of expansion of their economy. Women were noted to experience higher levels of work-family conflict cross-culturally. Similarly, in their studies, CalvoSalguero, Martínez-de-Lecea, \& del Carmen Aguilar-Luzón (2012) noted that because women work more hours at home than men, they experience an extreme state of work-family conflict because of combining their job as well as family role. Likewise, in a similar study, Chung and van der Lippe (2020) noted that a significant difference exists in gender concerning the experience of work-life balance. More specifically, female workers 
were more incentivized to attain work balance through their ability to have control over their working schedule, unlike men, and subsequently remain the same with some of the results reported by researchers.

Nevertheless, in a survey on the significance of gender differences in labor and household duties, Cinamon and Rich (2002) observed that there are no significant differences in gender as far as work-family conflict is concerned (Cinamon \& Rich, 2002). Consistent with Cinamon and Rich's (2002) results, Mcelwain, Korabik, \& Rosin (2005) also reported that work-family conflict does not differ among males and females. Furthermore, in an investigation on the nexus of gender and work-family conflict, Shockley, Shen, DeNunzio, Arvan, and Knudsen (2017) observed no significant difference between men and women work-family conflict is concerned. More recently, in a study conducted on work-family conflict and its associations with the engagement of work, Lyu, and Fan (2020) opined that gender differences do not significantly exist in workfamily conflict. From the initial literature review, it is apparent that there is no consensus on a significant difference exist in WFC concerning gender as some studies reported a significant difference, with others reporting otherwise. Again, it is unclear whether WFC will differ concerning gender in the Ghanaian context where the extended family system has been identified to be gradually weakened (Abotchie, 2008; Annor, 2016a; Nukunya, 2003). In congruence with the direction of the literature review, it thus hypothesized that;

H1: There is no significant difference in the work-family conflict between males and females.

\section{Job Demand and Work-Family Conflict}

Literature has considered the effect concerning job demand and work-family conflict in the working environs. An employee's workload can influence one's attitude and responsibility in the work and family domain. For instance, Adisa et al. (2016) in their study reported that job demand has a positive effect on workfamily conflict. Their study reported that work domain pressure and that of the household are some of the contributing factors to work-family conflict. They emphasized that when the workload is huge, employees are likely to experience fatigue and burnout, which becomes difficult for them to give the necessary attention to the family domain. This supports the spillover theory since an employee who experiences a rough period at the workplace tends to transfer such disposition to the household. Again, Eunice et al. (2018) researched workfamily conflict and burnout among nurses in Ghana. Of keen interest to the researchers was to investigate job and household demands as indicators of work-family conflict and the association between work and household conflict amongst nursing professionals. Eunice et al. (2018) specified that due to the demanding nature of nurse professionals, they are open to different kinds of workplace stressors such as emotional expectancy of patients, pain and death, fatigue, and sufficient reserves to manage such stressors problematic. The demands on nurses in many developing. Eunice et al. (2018) found that the long working hours of nurses contribute to a high level of WFC within the Ghana Health Service (GHS) since they spend long hours at work than their family domain. This makes it challenging for nurses to manage their job and household responsibilities and their work lives.

Similarly, Carlson, Thompson, and Kacmar (2019) examined the spillover and crossover effects of work demands on the family outcomes. The findings indicated that work-family conflict and family-work conflict both interrelated negatively with outcomes and positively with negative outcomes. That is, it revealed that strain experienced by work demand-pull over to the family domain and subsequently crosses again to the job environs to impact the output and commitment of the individual badly. Similarly, Duong, Hussain, and Subramaniam (2020) investigated the effects and importance of work strain, staff support, and work-life balance among working women in Vietnam. The study aimed to investigate the work-life balance difficulties confronted by working women in a worldwide organization in Vietnam. The study then indicated that insufficient resources, incompatible demands, and distinguishing operational style might cause stress effects on work-life balance (Duong et al., 2020). Deducing from the review above, it is hypothesized that;

H2: Job demand has a positive effect on work-family conflict. 


\section{Job Support and Work-Family Conflict}

Many researchers have attempted to predict the impact between job support and work-family. Available literature has thus confirmed this prediction. For example, job support has been found to influence work-family negatively. This implies that when an employee is given the needed support, their work-family conflict is reduced. Thus, the work-family conflict will decrease if organizations implement flexible and favorable work environs where individuals can manage job and household duties. Thakur, Bansal, and Maini (2018) indicated in their research that job sharing as a strategy for a flexible work system creates a model of approval for housewives. This, therefore, would enable housewives to balance both family activities and work life. Again, workplace flexibility, support, and judgemental attitude significantly affect work-family conflict. Work interference with household obligations and job flexibility was a study investigated by (Halinski \& Duxbury, 2019). The objective of the study was to re-address the job environs' flexibility. Halinski and Duxbury (2019) found in their study that employees can balance work with family responsibilities when organizations operationalize flexibility, which is the capacity of an employee to determine the time, place, and duration of their job, enabling them to accommodate personal and family commitment. This explains that organizations need to implement flexible work arrangement policies to aid employees in managing predictable and family demands as and when they occur. Again, their study revealed associating reactive flexibility to workplace policies. They emphasized that reactive flexibility at the workplace lessens the adverse impact of work and household conflict on strain enabling workforces to cope with unreliable issues at home in a sound manner. Correspondingly, Duong et al. (2020) investigated the effects and importance of work strain, staff support, and work-life balance among working women in Vietnam. The study aimed to investigate the work-life balance difficulties confronted by women working in a worldwide organization in Vietnam. Their findings indicated that when there are insufficient resources, incompatible demands, and distinctive working styles, it could cause job pressure or stress effects on work-life balance (Duong et al., 2020). Upon the preceding literature review, it is hypothesized that;

H3: Job support has a negative impact on work-family conflict.

\section{Methodology}

\section{Research Design}

The descriptive survey research was adopted in this study since it was perceived as the most appropriate in describing the variables expressed in the sections. This consideration is grounding on the Sekaran and Bougie (2016) views, which purports that the survey method presents the most effective paradigm for collecting data in a finite population in a snapshot of time. In the same breath, Sarantakos (2013) contended that a survey is suitable to collect information systematically at a specific point in time, intending to describe exiting situations.

\section{Target Population.}

According to Sarantakos (2013), the target population is a complete collection of people or events of interest to the researcher. The study's target population comprises the employees in some selected banking institutions. Currently, there are 23 licensed commercial banks in Ghana. The current study targeted four banking institutions in Takoradi since the researchers are all based in Takoradi and for time and economic reasons. The four banks used in this study had a population of 120 employees.

\section{Sampling Technique and Sample}

According to Sekaran and Bougie (2016), sampling denotes the act of choosing members of a given populace to represent their entirety on a subject of interest. In other words, the procedure of choosing adequate elements from the populace so that results from analyzing the sample are generalizable to the population. Since 
the target population for the four banks yielded 120 respondents, it was prudent the study used all of them. Accordingly, the census approach was adopted for this study. This was to ensure the generalizability of the findings to the entire workforce in the banking sector of Ghana. Although 120 questionnaires were issued, 85 were returned. Of these, 53 respondents representing 62.4\%, were males, whiles 32 respondents representing $37.6 \%$, were females. This indicates that the majority of the respondents were males.

\section{Measures/Instruments.}

Google forms were used to develop the questionnaire and administered to the various participants online due to the current COVID-19 Pandemic, which was severe when the survey was carried out. The multiple constructs that made up the questionnaire are as presented below.

Job demand was measured borrowing 4 of the items developed by Karasek and Theorell (1990) and had the reliability of 0.726 . An example of the items in the questionnaire is: "My job requires working very fast."

Job support was assessed using three support facets: co-worker support, supervisory support, and organizational support. Co-worker support was measured borrowing 3 of the items developed by Susskind, Kacmar, and Borchgrevink (2003). For example, "My co-worker supports me emotionally when I am down." Also, supervisory support was measured using 2 of Susskind et al. (2003). An example of the items was "I find my supervisor very helpful in performing my banking duties." Organizational support was measured using 5-items developed by Eisenberger, Huntington, Hutchison, and Sowa (1986). An example of the items in their questionnaire includes: "The organization cares about my well-being." Each facet had a suitable Cronbach's $\alpha$; 0.726 for co-worker support, 0.845 for supervisory support, and 0.820 for organizational support.

Work-Family Conflict: There are two dimensions of work-family conflict: work-to-family conflict (WFC) and family-to-work conflict (FWC), but this study was only interested in measuring work-to-family conflict with the reliability of 0.852 . WFC was measured using the 9-items scale developed by Carlson, Kacmar, and Williams (2000). An example of an item in the instrument is: "I am often so emotionally drained when I get home from work that it prevents me from contributing to my family."

\section{Results and Discussion}

This section presents data analysis, findings, and interpretation of the study according to the research hypotheses. The first hypothesis sought to investigate whether work-family conflict differs among male and female employees in the banking sector, and the results are shown in Table 1.

Table 1: Independent Samples Test

\begin{tabular}{|c|c|c|c|c|c|c|c|c|c|}
\hline & \multicolumn{2}{|c|}{$\begin{array}{l}\text { Levene's } \\
\text { Test } \\
\text { Equality } \\
\text { of } \\
\text { Variances }\end{array}$} & t-test & or Equa & ity of $M$ & ans & & & \\
\hline & \multirow[b]{2}{*}{ F } & \multirow[b]{2}{*}{ Sig } & \multirow[b]{2}{*}{$\mathrm{t}$} & \multirow[b]{2}{*}{ df } & \multirow[b]{2}{*}{$\begin{array}{l}\text { Sig }(2- \\
\text { tailed })\end{array}$} & \multirow[b]{2}{*}{$\begin{array}{l}\text { Mean } \\
\text { Difference }\end{array}$} & \multirow[b]{2}{*}{$\begin{array}{l}\text { Std. Error } \\
\text { Difference }\end{array}$} & \multicolumn{2}{|c|}{$\begin{array}{l}95 \% \text { Confidence } \\
\text { interval of the } \\
\text { difference }\end{array}$} \\
\hline & & & & & & & & Lower & Upper \\
\hline Equal Variances assumed & .988 & .323 & -.439 & 83 & .662 & -.070 & .159 & -.387 & .247 \\
\hline $\begin{array}{l}\text { Equal variances not } \\
\text { assumed }\end{array}$ & & & -.460 & 75.284 & .647 & -.070 & .152 & -.372 & .233 \\
\hline
\end{tabular}

From table 1, the $\mathrm{P}$-value is equal to 0.662 , which is greater than alpha $(\alpha)(\mathrm{P}>0.05)$. This makes the test not significant at a 5\% significant level. This implies that there is not enough evidence to support the 
statement that work-family conflict differs concerning gender. As a result, work-family conflict does not significantly differ among males and females. Hence, we failed to reject hypothesis 1 and concluded that at 0.05 significant level, work-family conflict does not differ among males and females in the banking sector of Ghana.

\section{Effect of job demand and job support on employees' experience of work-family conflict}

This subsection sought to investigate the effect of job demand and job support on employees' experience of work-family conflict. Accordingly, it was hypothesized that;

H2: Job demand has a positive impact on work-family conflict

H3: Job support has a negative impact on work-family conflict.

\section{Reporting Multiple Linear Regression In APA}

$\mathrm{DV}=$ Dependent Variable $=$ Work-family conflict $(\mathrm{Y})$

IV1 = Independent Variable $=$ Job demand $(\mathrm{X} 1=0.170)$

IV2 = Independent Variable $=$ Job support $(\mathrm{X} 2=0.301)$

Multiple linear regression was calculated to predict work-family conflict (DV) on job demand (IV1) and job support (IV2). A significant regression equation was found $(\mathrm{F}(2,82)=3.889, p<0.024)$, with an $R^{2}$ of 0.087. Participants' predicted work-family conflict equals $4.067+0.170$ (job demand) - 0.301 (job support), where job demand is coded as demand, and job support is coded as support. Participants' work-family conflict increased by 0.170 for each level of job demand and decreased by 0.301 for each level of job support. Both predictors had a significant impact on work-family conflict.

Therefore, the final regression equation

$$
\begin{aligned}
& \mathrm{Y}=\beta \mathbf{0}+\beta 1 \mathrm{X} 1+\beta 2 \mathrm{X} 2+\varepsilon \\
& \mathrm{Y}=\text { dependent variable } \\
& \beta \mathbf{0}=\text { Constant (population intercept of } \mathrm{Y} \text { ) } \\
& \beta 1=\text { Population slope coefficient } \\
& \mathrm{X}=\text { Independent variable } \\
& \mathcal{E}=\text { standardized error } \\
& \mathrm{Y}=4.067-0.294 \mathrm{X} 2+0.691
\end{aligned}
$$

Table 2: Model Summary

\begin{tabular}{|c|c|c|c|c|c|c|}
\hline \multicolumn{2}{|c|}{ Model } & Sum of Squares & df & Mean Square & \multirow{2}{*}{$\begin{array}{l}\mathbf{F} \\
3.889\end{array}$} & \multirow{2}{*}{$\begin{array}{l}\text { Sig. } \\
.024^{\mathrm{b}}\end{array}$} \\
\hline 1 & Regression & 3.653 & 2 & 1.826 & & \\
\hline & Residual & 38.505 & 82 & .470 & & \\
\hline & Total & 42.157 & 84 & & & \\
\hline \multicolumn{7}{|c|}{$\begin{array}{l}\text { a. Dependent Variable: WFC } \\
\text { b. Predictors: (Constant), Job Support, Job Demand }\end{array}$} \\
\hline
\end{tabular}

\begin{tabular}{lllll}
\hline Model & R & R Square & Adjusted R Square & Std. Error of the Estimate \\
\hline 1 & $.294^{\mathrm{a}}$ & .087 & .064 & .685 \\
a. Predictors: (Constant), Job Support, Job Demand & \\
\hline
\end{tabular}

From table 2, Pearson correlation coefficient $(\mathrm{R})=0.294$. This suggests that the coefficient of determination $\left(R^{2}\right)=0.087$ which is $0.087 \times 100=8.7 \%$. The value of $\left(R^{2}\right)=8.7 \%$, implies that $8.7 \%$ of the variation in the work-family conflict of an employee can be attributed to job demand and job support, and the other $91.3 \%$ can be attributed to other factors not used in the study.

Table 3: ANOVA 
Table 4: Coefficients ${ }^{a}$

\begin{tabular}{|c|c|c|c|c|c|c|}
\hline \multirow{2}{*}{\multicolumn{2}{|c|}{ Model }} & \multicolumn{2}{|c|}{ Unstandardized Coefficients } & \multirow{2}{*}{$\begin{array}{l}\text { Standardized Coefficients } \\
\text { Beta }\end{array}$} & \multirow[t]{2}{*}{$\mathbf{t}$} & \multirow[t]{2}{*}{ Sig. } \\
\hline & & B & Std. Error & & & \\
\hline 1 & (Constant) & 4.067 & .691 & & 5.885 & .000 \\
\hline & Demand & .205 & .134 & .170 & 1.526 & .031 \\
\hline & Support & -.465 & .172 & -.301 & -2.702 & .008 \\
\hline
\end{tabular}

From the coefficient Table 4, job demand has a standardized coefficient beta of 0.170 . This implies that job demand has a positive impact on work-family conflict. The P-value from the same table is 0.031 , which is less than alpha (0.05) at a 5\% significant level. This implies that job demand has a significant positive effect on work-family conflict. It can be deduced from the analysis that at a 95\% confidence level, work-family conflict is likely to be high if the job is too demanding. On the other hand, work-family conflict is likely to be low if job demand is low. Per this finding, we failed to reject hypothesis 2 at a 0.05 level of significance and conclude that job demand has a significant positive effect on work-family conflict.

Moreover, the coefficient Table 4 shows that job support has a beta value of -0.301 . This implies that job support has a negative impact on work-family conflict. The P-value from the table is 0.008 , which is less than alpha (0.05) at a 5\% significant level. This implies that job support has a significant negative effect on work-family conflict. It could be concluded from the analysis that a $95 \%$ confidence level of work-family conflict is likely to be low if the level of job support is enhanced. On the other hand, the level of work-family conflict is likely to be high if job support is low. Therefore, we failed to reject hypothesis 3 at a 0.05 level of significance and conclude that job support has a negative effect on work-family conflict.

\section{Discussion}

\section{The difference between male and female employees on work-family conflict in the banking sector.}

Our first objective in the study was to investigate whether work-family conflict differs among male and female employees in the banking sector. The findings of this objective concluded that there is no statistically significant difference in the work-family conflict between males and females. In their studies, Mcelwain et al. (2005) also reported that there is no significant difference in work-family conflict among males and females, which supports our current finding. Organizations currently have adapted to the flexible working system, such as flexible working hours, where each employee balances their work and family role. Also, in the Ghanaian context, our culture promotes collectivism where extended family provides the necessary support to family members irrespective of their gender. This support, however, enables employees in the banking sector to balance their work and family activities. In a similar study, Cinamon and Rich (2002) observed no significant differences in gender as far as work-family conflict is concerned. However, work-family conflict was determined by the amount of time an employee spends in both domains (work and family).

\section{The effect of job demand and job support on employees' experience in work-family conflict}

This study aimed to examine the effect of job demand and job support on employees' experience of work-family conflict. Our findings revealed that job demand has a positive effect on work-family conflict. This means that as an employee's job becomes demanding, their work-family conflict will also increase and vice versa. This finding is consistent with the previous results obtained by Adisa et al. (2016), who observed that job demand positively affects work-family conflict. Their findings reported that pressure from the job and home domains contributes to work-family conflict. They emphasized that when the workload is huge, employees are likely to experience fatigue and burnout, which becomes difficult for them to give the necessary attention to 
the family domain. Moreover, our findings on the nexus of job demand and work-family conflict is in line with the results of Eunice et al. (2018) who reported that long working hours of nurses contribute to a high level of WFC within the Ghana Health Service (GHS) since they spend long hours at work than their family domain.

Another finding in this study is that job support was observed to have a negative effect on work-family. This means when job support is high, an employee will experience a low level of work-family conflict and vice versa. Organizations implement a flexible and favorable working environment where employees can balance their work and family responsibilities, hence, their work-family conflict will decrease. This result is consistent with earlier findings by Thakur et al. (2018), who also indicated in their research that job sharing as a strategy for a flexible work system creates healthy well-being for housewives. This, therefore, would enable housewives to balance both family activities and professional lives. Similarly, our findings on the nexus of job support and work-family conflict are supported by the report of Halinski and Duxbury (2019), which posits that employees can balance work with family responsibilities when organizations operationalize flexibility, that is, the capacity of an employee to make choices determining time, place and duration of their job enables them to accommodate personal and family commitment. This indicates that organizations can assist their workforce in dealing with challenges associated with work-family integration by churning out family-friendly human resource policies and practices that can cushion them against the job demands.

\section{Conclusion}

From the findings of this study, we concluded that work-family conflict does not significantly differ between males and females. It could also be deduced that, as an employee's job becomes demanding, the level of work-family conflict tends to increase. This explains that pressures from the work domain are unequivocally a contributing factor to work-family conflict. Therefore, when the workload is enormous, employees are likely to experience fatigue and burnout, which becomes challenging for them to give the needed attention to the family domain. Again, it is concluded that as job support increases, an employee is likely to experience a low level of work-family conflict, resulting from a flexible and favorable working environment where employees can balance their work and family responsibilities.

\section{Limitation and Future Direction}

Like much other academic research, this study is fraught with several limitations worthy of note. Firstly, although the issue of work-family conflict is markedly pronounced in the banking sector of Ghana, the sample size used in the study was not huge enough to facilitate the generalization of the findings larger population. Accordingly, future studies can replicate this study with larger samples to ascertain if similar results are likely. Likewise, the use of a descriptive survey truncates one's ability to study a phenomenon over time to establish a cause-and-effect relationship. Hence future studies can employ longitudinal designs to follow the participants over time to overcome this drawback.

Funding: This research received no external funding.

Acknowledgments: We acknowledge there was no external funding support; all authors contributed accordingly in every part of the paper.

Conflicts of Interest: The authors declare no conflict of interest.

\section{References}

Abotchie, C. (2008). Social Structure of Modern Ghana. Accra: Hans Publication.

Adisa, T. A., Osabutey, E., \& Gbadamosi, G. (2016). Understanding the causes and consequences of workfamily conflict: An exploratory study of Nigerian employees. Employee Relations, 38(5), 770-788.

https://doi.org/10.1108/ER-11-2015-0211 
Annor, F. (2016a). Work-Family Conflict: A Synthesis of the Research from Cross-National Perspective. Journal of Social Sciences, 12(1), 1-13. https://doi.org/10.3844/jssp.2016.1.13

Annor, F. (2016b). Work-family demands and support: Examining direct and moderating influences on work-family conflict. Journal of Workplace Behavioral Health, 31(2), 87-103. https://doi.org/10.1080/15555240.2015.1119656

Carlson, D. S., Thompson, M. J., \& Kacmar, K. M. (2019). Double crossed: The spillover and crossover effects of work demands on work outcomes through the family. Journal of Applied Psychology, 104(2), 214 228. https://doi.org/10.1037/apl0000348

Chandra, V. (2012). Work-life balance: eastern and western perspectives. International Journal of Human Resource Management, 23(5), 1040-1056. https://doi.org/10.1080/09585192.2012.651339

Cinamon, R. G., \& Rich, Y. (2002). Gender differences in the importance of work and family roles: Implications for work-family conflict. Sex Roles, 47(11-12), 531-541. https://doi.org/10.1023/A:1022021804846

Duong, M. T., Hussain, I. A., \& Subramaniam, A. (2020). Job stress, co-worker support, role expectation conflict and work-life balance among working women: A Quantitative study on Multinational Companies in Vietnam. Test Engineering and Management, 82(1-2), 744-749.

Eisenberger, R., Huntington, R., Hutchison, S., \& Sowa, D. (1986). Perceived organizational support. Journal of Applied Psychology, Vol. 71, pp. 500-507. US: American Psychological Association. https://doi.org/10.1037/0021-9010.71.3.500

Eunice, E., Asiedu, A., Annor, F., \& Baah, K. D. (2018). Juggling family and professional caring: Role demands, work - family conflict and burnout among registered nurses in Ghana. (May), 611-620. https://doi.org/10.1002/nop2.178

Fila, M. J. (2016). The Job Demands , Control, Support Model: Where Are We Now? TKM: International Journal for Research in Management, 1(1), 15-44.

Halinski, M., \& Duxbury, L. (2019). Workplace flexibility and its relationship with work-interferes-withfamily. Personnel Review, 49(1), 149-166. https://doi.org/10.1108/PR-01-2019-0048

Karasek, R., \& Theorell, T. (1990). Healthy Work: Stress, Productivity and the Reconstruction of Working Life. New York: Basic Books Inc,.

Kundu, S. C., Phogat, R. S., Datta, S. K., \& Gahlawat, N. (2016). Impact of workplace characteristics on work-family conflict of dual-career couples. International Journal of Organizational Analysis, 24(5), 883-907. https://doi.org/10.1108/IJOA-01-2015-0840

Lyu, X., \& Fan, Y. (2020). Research on the relationship of work family conflict, work engagement and job crafting: A gender perspective. Current Psychology. https://doi.org/10.1007/s12144-020-00705-4

Mansour, S., \& Tremblay, D. G. (2018). Work-family conflict/family-work conflict, job stress, burnout and intention to leave in the hotel industry in Quebec (Canada): moderating role of need for family friendly practices as "resource passageways." International Journal of Human Resource Management, 29(16), 2399-2430. https://doi.org/10.1080/09585192.2016.1239216

Martínez-León, I. M., Olmedo-Cifuentes, I., \& Sanchez-Vidal, M. E. (2019). Relationship between availability of WLB practices and financial results. Personnel Review, 48(4), 935-956. https://doi.org/10.1108/PR-122017-0402

Mcelwain, A. K., Korabik, K., \& Rosin, H. M. (2005). An examination of gender differences in work-family conflict. Canadian Journal of Behavioural Science, 37(4), 283-298. https://doi.org/10.1037/h0087263

Michel, J. S., Kotrba, L. M., Mitchelson, J. K., Clark, M. A., \& Baltes, B. B. (2011). Antecedents of workfamily conflict: A meta-analytic review. Journal of Organizational Behavior, 32(5), 689-725. https://doi.org/10.1002/JOB.695

Morrison, D. A., Mensah, J. V., Kpakpo, G. N. A., \& Asante, C. (2020). Work-family conflict and employee performance in Ghana's banking sector. International Journal of Research -Granthaalayah, 8(9), 113-122. https://doi.org/10.29121/granthaalayah.v8.i9.2020.1120

Nukunya, G. K. (2003). Tradition and Change in Modern Ghana: An Introduction to Sociology (2nd ed.). Accra: 
Ghana University Press.

Oren, L., \& Levin, L. (2017). Work-family conflict/enrichment: the role of personal resources. International Journal of Manpower, 38(8), 1102-1113. https://doi.org/10.1108/IJM-06-2014-0135

Osei Boakye, A., Dei Mensah, R., Bartrop-Sackey, M., \& Muah, P. (2021). Juggling between work, studies and motherhood: The role of social support systems for the attainment of work-life balance. $S A$ Journal of Human Resource Management, 19(0), 10. https:/ / doi.org/10.4102/SAJHRM.V19I0.1546

Regeria, M., \& Nairobi, O. (2017). Effects Of Work-Family Conflict On Job And Life Satisfaction Among Staff Of The State Department Of Coordination, Ministry Of Interior And Coordination Of National Government.

Sarantakos, S. (2013). Social Research (4th ed.). Hampshire: Palgrave Macmillan.

Sekaran, U., \& Bougie, R. (2016). Reserach Methods for Bussiness A Skill-Bulding Approach. In Printer Trento Srl (7th edn). John Wiley \& Sons.

Shockley, K. M., Shen, W., DeNunzio, M. M., Arvan, M. L., \& Knudsen, E. A. (2017). Disentangling the relationship between gender and work-family conflict: An integration of theoretical perspectives using meta-analytic methods. Journal of Applied Psychology, Vol. 102, pp. 1601-1635. Shockley, Kristen M.: Department of Psychology, University of Georgia, 125 Baldwin Street, Athens, GA, US, 30602, kshock@uga.edu: American Psychological Association. https://doi.org/10.1037/ap10000246

Sok, J., Blomme, R., \& Tromp, D. (2014). Positive and Negative Spillover from Work to Home: The Role of Organizational Culture and Supportive Arrangements. British Journal of Management, 25(3), 456-472. https://doi.org/10.1111/1467-8551.12058

Staines, G. L. (1980). Spillover Versus Compensation: A Review of the Literature on the Relationship Between Work and Nonwork. Human Relations, 33(2), 111-129. https://doi.org/10.1177/001872678003300203

Starmer, A. J., Frintner, M. P., Matos, K., Somberg, C., Freed, G., \& Byrne, B. J. (2019). Gender Discrepancies Related to Pediatrician Work-Life Balance and Household Responsibilities. Pediatrics, 144(4). https://doi.org/10.1542/peds.2018-2926

Susskind, A. M., Kacmar, K. M., \& Borchgrevink, C. P. (2003). Customer service providers' attitudes relating to customer service and customer satisfaction in the customer-server exchange. Journal of Applied Psychology, Vol. 88, pp. 179-187. Susskind, Alex M.: Cornell U, School of Hotel Administration, 250 Statler Hall, Ithaca, NY, US, 14853, ams76@cornell.edu: American Psychological Association. https://doi.org/10.1037/0021-9010.88.1.179

Thakur, M., Bansal, A., \& Maini, R. (2018). Job sharing as a tool for flexible work systems: Creating opportunities for housewives in the Indian labor market. Gender in Management, 33(5), 350-366. https://doi.org/10.1108/GM-08-2016-0149 